\author{
돼지 심장으로부터 획득한 수리미유사물이 프랑크푸르트 소시지의 \\ 품질에 미치는 영향 \\ 문성실** . 강근호* . 양한술* . 박구부* . 주선태* \\ 경상대학교 동물자원과학부*, 충남동물자원센터**
}

\title{
Influence of Surimi-like Material (SLM) from Pig Heart on the Quality of Frankfurter Sausage
}

\author{
S. S. Moon**, G. H. Kang*, H. S. Yang*, G. B. Park* and S. T. Joo*
}

Division of Animal Science, College of Agriculture and Life Science, Gyeongsang National University*, The Chungnam Animal Science Center, Korea**

\begin{abstract}
Effects of surimi-like material (SLM) from pig heart on the quality of frankfurter sausage were investigated. The sausages were made by substituted addition of SLM at 5 and $10 \%$ levels in raw meats. Contents of moisture and fat in batter were not changed by addition of SLM, respectively, whereas protein content was significantly $(\mathrm{P}<0.05)$ decreased with $\mathrm{SLM}$ level increased. Although $\mathrm{pH}$ of frankfurter sausage was significantly $(\mathrm{P}<0.05)$ increased with SLM addition, percentage of cook yield was significantly $(\mathrm{P}<0.05)$ decreased. As increasing of addition levels of SLM, hardness and chewiness were decreased, but springiness was significantly $(\mathrm{P}<0.05)$ increased. Also, panel rated sausages of $10 \%$ SLM as having a higher tenderness and acceptability compared with control. These results suggested that a tender frankfurter sausage without any defects of flavor might be made with substitution of SLM from pig heart.
\end{abstract}

(Key words : Surimi-like material, Frankfurter, Texture, Sensory analysis)

$$
\text { I. 서 론 }
$$

국내에서 판매되고 있는 육제품 중 많은 제 품들이 생산가격을 낮추기 위해 연육을 사용하 고 있는데, 대표적인 제품으로는, 어린이들이 즐겨 먹는 어육소시지가 있다. 상업적으로 사 용되고 있는 연육은 어육을 수세하여 획득하는 어육단백질을 말하며, 일반적으로 ‘수리미’라는 용어로 불리고 있다. 근육식품가공업계에서는 이러한 수리미를 이용하여 다양한 제품들을 개 발하여 시판하고 있는데, 그 종류로는 게맛살,
새우맛살, 조개맛살 등 다양한 제품들이 있으 며, 향후 육가공산업에서도 이러한 수리미를 이용한 제품 개발이 활발히 이루어질 것으로 예상된다.

한편, 최근에는 어육이 아닌 축육으로부터 가공적성이 우수한 수리미를 획득하는 것에도 관심이 높아지고 있는데, 특히 소와 돼지의 심 장, 혀 및 볼살 등과 같은 식육부산물로부터 제조 된 수리미유사물의 특성에 대해 많은 연구가 진 행되고 있다(Srinivasan 등, 1996; Antonomanolaki 등, 1999; Nowsad 등, 2000; Kang 등, 2003;

Corresponding author : Seon Tea Joo, Meat Science Laboratory, Division of Animal Science and Technology, College of Agriculture and Life Science, Gyeongsang National University, Jinju 660-701, Korea. Tel : 055-751-5511, Fax : 055-756-7171, E-mail : stjoo@gsnu.ac.kr 
Totosaus, 2004). 그러나 축육을 이용한 수리미 의 연구들은 대부분 열처리에 의한 젤의 특성 (Xiong과 Blanchard, 1994; Park 등, 1996a), 분쇄 육과 조제된 근원섬유단백질에 대한 젤의 특성 (Park 등, 1996b), 수리미 제조시 근원섬유단백 질의 항산화(Srinivasan 등, 1996) 등과 같은 연 구에 집중되어 왔으며, 심장과 같은 도축 후 식육부산물에서 추출한 수리미를 햄과 소시지 와 같은 육가공제품 제조시 값비싼 원료육의 대체제로 사용하는 것에 대한 연구는 그리 많 이 이루어지지 않았다.

Kang 등(2003)은 돼지 심장으로부터 추출된 수리미유사물을 이용하여 유화형소시지 제조하 였고, Desmond와 Kenny(1998)는 소 심장에서 추출된 수리미유사물을 이용하여 프랑크푸르트 소시지의 제조 가능성에 대해서 보고하였다. 상기 두 연구에 따르면 소나 돼지의 심장으로 부터 추출된 수리미유사물을 혼합하여 육제품 을 제조하면 풍미가 향상되는 장점이 있지만 심장 수리미유사물 자체의 색깔이 연갈색을 보 이는 것으로 밝혀졌다. 따라서 식육동물의 심 장으로부터 획득한 수리미유사물을 프랑크푸르 트와 같은 육제품을 제조할 때 원료육의 일정 량 대체제로 사용하면 풍미와 제품의 색을 개 선시킬 수 있을 것으로 사료된다. 하지만 우리 나라에서는 소의 심장이 식육부산물임에도 불 구하고 경제적 가치가 높기 때문에 수리미유사 물 획득에 사용하기에는 부적당하다. 값싼 돼 지 심장의 경우 그로부터 추출한 수리미유사물 을 육제품 제조시 원료육의 대체제로 사용할 경우 경제적 이용성은 높지만, 제품의 물리적 특성과 관능적 특성에 미치는 영향에 대해서는 많은 연구가 이루어지지 않았다.

따라서 본 연구에서는 돼지 심장에서 추출한 수리미유사물을 원료육의 대체제로 사용하여 프랑크푸르트 소시지를 제조한 후 품질특성을 알아보기 위해 제품의 일반성분, $\mathrm{pH}$, 조리수율, 물리적 특성 및 관능적 특성을 조사하였다.

\section{ㅍ. 재료 및 방법}

\section{1. 샘플채취 및 수리미유사물 제조}

일반상업용 도축장에서 도축직후 돼지 심장을 채취하여 실험실로 이송한 후, 과도한 바깥 결 체조직을 제거시키고 적육을 약 $2 \mathrm{~cm}^{3}$ 로 잘라 5 배의 얼음물과 함께 균질기를 이용하여 균질하 였다. 수리미유사물의 제조는 Park 등(1996a)의 방법을 변형하여, 현탁액속의 결체조직을 제거 하기 위해 $2 \mathrm{~mm}$ 금속체에서 거른 후, 다시 치 즈천을 통과시켜 $2,000 \times \mathrm{g}, 4^{\circ} \mathrm{C}$ 에서 15 분간 원 심분리하여 상등액은 버리고 근원섬유단백질 추출물인 잔사를 획득하였다. 이것을 다시 5 배 의 얼음물과 함께 균질한 후 치즈천으로 여과 시키고 다시 원심분리 하였다. 이러한 수세과 정을 3회 반복하여 수리미유사물을 획득한 후, 수리미유사물의 일반성분을 분석하였으며, 수 분 $82.85 \%$, 조단백 $15.38 \%$, 조지방 $1.15 \%, \mathrm{pH}$ 는 6.86 이었다. 동결 중 단백질 변성을 방지하기 위해 중량대비 $3 \% \mathrm{NaCl}, 0.5 \%$ tripolyphosphate 및 $4 \%$ sorbitol을 첨가하여 $-60^{\circ} \mathrm{C}$ 에서 저장하면 서 프랑크푸르트 소시지 제조에 이용하였다.

소시지의 제조는 일반적으로 이용되는 프랑 크푸르트 소시지 제조방법에 따라 실시하였으 며, 제조에 이용된 우육과 돈육의 반막양근은 일반 정육점에서 구입되었다. 원료육의 비용 절 감을 위한 수리미유사물의 대체는 소시지 제조 시 투입되는 원료육을 기준으로 그 함량을 처 리구 별로 달리하였으며(Table 1), 각각 8 batch $(n=8)$ 의 소시지를 만들어 실험에 이용하였다. 프랑크푸르트 소시지의 품질 특성 중 가열수율 은 가열 전의 소시지와 가열 후 소시지의 무게 차에 의해 계산되어 이용하였으며, 그 외 소시 지의 일반성분, $\mathrm{pH}$, 조직감 및 관능평가를 위 해서는 유화물을 cellulose casing(Viscofon, Food Process Technology Ltd)에 충진한 후 증기챔버 로 심부온도를 $71^{\circ} \mathrm{C}$ 로 가열한 후 흐르는 수돗 물에 냉각하여 이용하였다.

\section{2. 일반성분, $\mathrm{pH}$ 및 가열수율}

일반성분 및 $\mathrm{pH}$ 분석을 위해 가열된 소시지 의 케이싱을 제거한 후, 블랜드(Robot coupe blender)를 이용하여 샘플을 준비하였다. 각 처 리구의 수분과 지방 함량은 CEM 분석시스템을 
Table 1. Formulations for frankfurter sausages

\begin{tabular}{lccc}
\hline Items(\%) & Control & 5\% Surimi-like material & $10 \%$ Surimi-like material \\
\hline \hline Lean beef & 29.40 & 26.90 & 24.40 \\
Lean pork & 27.20 & 24.70 & 19.70 \\
Fat & 30.10 & 30.10 & 30.10 \\
Water & 11.00 & 11.00 & 11.00 \\
Salt & 1.50 & 1.50 & 1.50 \\
Spice mix & 0.50 & 0.50 & 0.50 \\
STPP & 0.25 & 0.25 & 0.25 \\
Sodium ascorbate & 0.05 & 0.05 & 0.05 \\
Surimi-like material (extract) & - & 5.00 & 10.00 \\
\hline
\end{tabular}

1) STPP: Sodium tripolyphosphate.

통해 측정하였으며(Bostian 등, 1985), 단백질 함량은 LECO Nitrogen Determinator에 의해 분 석하였다(Sweeny와 Rexford, 1987). $\mathrm{pH}$ 는 샘플 $3 \mathrm{~g}$ 을 증류수 $27 \mathrm{ml}$ 과 함께 균질기 (T25 basic, IKA, Malaysia)로 $1 \mathrm{~min} / 14,000 \mathrm{rpm}$ 간 균질하여 $\mathrm{pH}$-meter (MP230, Mettler Toledo, Swiss)로 측정 하였다. 샘플들은 각각의 반복 처리구 당 2 개 의 프랑크푸르트를 임의로 선정하여 측정하였 다. 가열수율은 가열전후의 샘플 무게의 차이 에 의해 계산하였다.

\section{3. 조직감 분석}

조직감(Texture profile analysis, TPA)은 가열된 프랑크푸르트 소시지를 이용하여 Bourne(1968) 의 방법에 의해 분석하였다. 처리구당 5 개의 코어(직경 $2.5 \mathrm{~cm} \times$ 높이 $2 \mathrm{~cm}$ )를 만들었으며, 2.5 $\mathrm{cm}$ 원통형 디스크를 이용하여 원래 높이의 $50 \%$ 까지 압착하여 분석하였다. Instron Universal Testing Machine Model 4464 (Instron (UK) Ltd., High Wycombe, UK)을 이용하여 측정하였으며, 분석 조건은 compression load cell $500 \mathrm{~N}$, table speed $120 \mathrm{~mm} / \mathrm{min}$ 이었다. 경도는 첫 번째의 압 축을 위해 필요한 힘으로 계산되었고, 응집성 은 첫 번째 압축에 대한 두 번째 압축동안 필 요한 힘의 비율에 의해 계산되었다. 탄력성은
첫 번째 압축 후 회복되는 샘플의 거리 $(\mathrm{mm})$ 로 산출되었으며, 씸힘성은 응집성과 탄력성에 의 해 계산되었다.

\section{4. 관능평가}

총 8 명의 관능요원이 프랑크푸르트 소시지의 관능적 특성을 평가하였다. 평가전에 관능요원 의 정확한 평가를 위해 다양한 종류의 프랑크 푸르트 소시지에 익숙해지기 위한 훈련을 실시 하였다. 각 샘플들은 $2 \mathrm{~cm}$ 두께로 일정하게 잘 라 육색, 연도, 다즙성, 풍미 및 기호성에 대해 6점 척도묘사법에 의해 평가되었다. 이때 육색 의 경우 $1=$ 매우 밝음, $6=$ 매우 짙음; 연도 $1=$ 매우 질김, $6=$ 매우 연함; 다즙성 $1=$ 매우 건 조, $6=$ 매우 다즙함; 풍미 $1=$ 매우 나쁨, $6=$ 매 우 좋음; 기호성 $1=$ 매우 나쁨, $6=$ 매우 좋음으 로 평가되었다.

\section{5. 통계분석}

실험에서 측정된 값들은 SAS(2001) 프로그램 을 이용하여 분산분석과 Duncan의 다중검정을 통해 $5 \%$ 수준에서 처리구간의 유의성을 검정 하였다. 


\section{III. 결과 및 고찰}

1. 프랑크푸르트 소시지 제조시 돼지 심장으 로부터 추출된 수리미유사물의 대체가 일 반성분, $\mathrm{pH}$ 및 가열수율에 미치는 영향

돼지 심장근육으로부터 획득한 수리미유사물 을 원료육과 함께 교반한 반죽상태에서 측정한 수분 함량과 지방 함량은 대조구와 처리구간에 유의적인 차이를 나타내지 않았다(Table 2).

그러나 단백질 함량에 있어서는 수리미유사 물 처리구가 대조구에 비해 유의적으로 $(\mathrm{P}<0.05)$ 낮게 나타났으며, $10 \%$ 수리미유사물 대체처리구 가 $5 \%$ 대체처리구에 비해 유의적으로 $(\mathrm{P}<0.05)$ 낮게 나타났다. 한편, 가열된 프랑크푸르트 소 시지의 $\mathrm{pH}$ 는 돼지 심장근육으로부터 추출된 수리미유사물의 함량이 증가함에 따라 유의적 으로 $(\mathrm{P}<0.05)$ 높게 나타났다(Table 3). 이와 같 은 결과는 돼지 심장근으로부터 추출된 근원섬 유 단백질의 $\mathrm{pH}$ 가 6.86으로, 그 자체의 영향보 다는 수리미유사물 내에 첨가된 소금과 인산염 의 함량이 상대적으로 높은 것에 기인하여 $\mathrm{pH}$ 가 상승된 것으로 사료된다. 일반적으로 소금과 인 산염과 같은 염 성분들은 육제품의 보수성에 영 향을 미치는데, 그 이유는 이온의 존재 하에서 단백질의 전기적 반발력 증가로 액틴과 마이오 신 필라멘트의 공간이 늘어나고 그 사이에 수 분이 차지하는 공간이 증가하기 때문이다 (Totosaus, 2004). 그러나 단백질 함량의 결과에 있어서는 돼지 심장근육으로부터 수리미유사물 제조시 근장단백질이 제거된 탓에 전체적인 단

Table 2. Effect of surimi-like material (SLM) from pig heart on proximate of frankfurter sausage

\begin{tabular}{lccc}
\hline Treatment & Moisture $\%$ & Fat \% & Protein $\%$ \\
\hline \hline Control & 53.4 & 28.22 & $15.23^{\mathrm{A}}$ \\
$5 \%$ SLM & 52.9 & 28.15 & $14.86^{\mathrm{B}}$ \\
$10 \%$ SLM & 53.1 & 28.18 & $13.75^{\mathrm{C}}$ \\
S.E.M & 0.54 & 0.12 & 0.18 \\
\hline
\end{tabular}

${ }^{\mathrm{A}-\mathrm{C}}$ Means with different superscripts within a column differ $(\mathrm{P}<0.05)$.
백질 함량이 줄어들어 대조구가 처리구에 비해 유의적으로 높게 나타난 것으로 사료된다.

프랑크푸르트 소시지의 가열수율 결과는 대 조구가 처리구에 비해 유의적으로 $(\mathrm{P}<0.05)$ 높은 것으로 나타났다(Table 3). 이 같은 결과는 프 랑크푸르트 소시지 제조시 수리미유사물 대체 함량이 높을수록 가열감량이 증가하는 것을 의 미한다. 이는 프랑크푸르트 소시지 제조시 돼 지 심장근육으로부터 추출된 근원섬유단백질은 쇠고기나 돼지고기 원료육에 비해 유화물 형 성이 잘 안되었거나 가열처리 동안 수분과의 결합이 원활히 이루어지지 않았기 때문인 것으 로 판단된다. 그러나 Desmond와 Kenny(1998)는 프랑크푸르트 소시지 제조시 소 심장으로부터 획득된 수리미유사물을 $15 \%$ 대체하였을 때, 대 조구에 비해 가열감량이 낮게 나타났다고 보고 하였다. 또한 Kang 등(2003)도 돼지 심장에서 추출한 수리미유사물을 유화형 소시지 제조시 돼지고기 원료육 함량에 대해 대체하였을 때 대조구가 수리미유사물 대체처리구에 비해 가 열감량이 높게 나타난 것으로 보고하였다. 상 기 두 연구에서 보고한 심장근육에서 추출된 근원섬유단백질의 가열감량이 원료육에 비해 우수하다는 결과는 본 실험의 결과와 다소 다 른 경향이다. 이는 아마도 소 심장과 돼지 심 장을 구성하고 있는 근원섬유단백질의 가공적 성의 차이나 쇠고기와 돼지고기를 원료육으로 사용한 프랑크푸르트 소시지와 돼지고기만을 원료육으로 하여 제조한 유화형 소시지의 차이 에 기인한 것으로 사료된다. 즉, Desmond와 Kenny(1998)의 결과와 본 연구의 결과를 비교

Table 3. Effect of surimi-like material (SLM) from pig heart on $\mathrm{pH}$, cook yield $\%$ of frankfurter sausage

\begin{tabular}{lcc}
\hline Treatment & $\mathrm{pH}$ & Cook yield (\%) \\
\hline \hline Control & $6.25^{\mathrm{B}}$ & $91.1^{\mathrm{A}}$ \\
$5 \%$ SLM & $6.28^{\mathrm{AB}}$ & $89.7^{\mathrm{AB}}$ \\
$10 \%$ SLM & $6.30^{\mathrm{A}}$ & $88.3^{\mathrm{B}}$ \\
S.E.M & 0.04 & 0.9 \\
\hline
\end{tabular}

${ }^{\mathrm{A}-\mathrm{B}}$ Means in the same column with different letters are different $(\mathrm{P}<0.05)$. 
하면, 소 심장을 이용하여 제조한 수리미유사 물이 돼지 심장으로부터 획득한 수리미유사물 에 비해 유화력이나 수분결합력이 우수하여 낮 은 가열감량을 나타낼 것으로 추정된다. 또한 Kang 등(2003)의 연구에서 유화형 소시지 제조 시 지방을 $20 \%$ 사용한 것을 감안하면, 돼지 심 장에서 획득한 수리미유사물은 소시지 배합비 내의 지방 함량에 따라 유화력과 가열감량이 영향을 받는 것으로 추정되며, 사용되는 지방의 함량이 증가할수록 수리미유사물의 원료육 대 체량을 줄이는 것이 가열감량을 줄이고 수율을 증가시키기 위해 바람직할 것으로 사료된다.

한편, 본 실험에서 $\mathrm{pH}$ 와 가열수율과의 관계 에 있어서는, 수리미유사물 대체 함량이 증가 함에 따라 $\mathrm{pH}$ 는 유의적으로 증가하였으나 가 열수율은 오히려 유의적으로 감소하는 것으로 나타났다. 일반적으로 육단백질에 소금을 첨가 할 경우 수분 함량이 증가하여 근섬유가 팽창 되고(Winger와 Pope, 1981), 소금의 첨가로 인해 근섬유는 붕괴되어 마이오신의 분해가 증가하 며, 분해된 마이오신은 젤 형성과 수분결합에 관여한다고 알려져 있다(Huxley, 1963). 그럼에 도 불구하고 본 실험에서 수리미유사물의 대체 량에 따라 $\mathrm{pH}$ 가 증가하였지만 가열수율이 낮 게 나타나 앞선 연구자들의 보고와 상반된 결 과를 보였다. 이는 심장근과 골격근을 구성하 고 있는 근원섬유단백질의 특성과 유화공정 및 가열처리시 가공적성의 차이에 기인한 것으로 사료된다. 따라서 향후 심장근과 골격근을 구 성하고 있는 근원섬유단백질의 가공적성에 대 해 심도 있는 연구가 이루어져야 할 것으로 사 료된다.

본 연구에서 돼지 심장에서 획득한 수리미유
사물의 원료육 대체첨가가 프랑크푸르트 소시 지 제조시 가열감량에 미치는 결과를 다른 연 구들의 결과들과 비교, 검토하여 종합하면, 소 의 심장으로부터 추출한 수리미유사물을 육제 품 제조시에 원료육 함량에 대해 대체할 경우 단일 축종과 프랑크푸르트 소시지와 같이 두 가지 축종의 근육을 이용한 육제품 제조시에는 가열수율이 높은 제품 생산이 가능한 것으로 판단된다. 그러나 돼지 심장근육으로부터 추출 한 수리미유사물과 가열감량과의 관계에 있어 서 단일 축종의 근육을 육제품 제조시에 원료 육 함량에 대해 대체할 경우에는 긍정적이지 만, 프랑크푸르트 소시지와 같이 두 가지 축종 의 근육을 이용한 육제품 제조시에는 부정적인 영향을 미치는 것으로 사료된다. 따라서 향후 이러한 근본적인 문제를 명확하게 밝히기 위해 서는 소와 돼지 심장으로부터 추출된 근원섬유 단백질의 특성에 대해서 보다 세밀한 연구가 있어야 할 것으로 사료된다. 또한, 심장과 같은 식육부산물로부터 획득된 근원섬유단백질을 육 제품 제조시에 원료육 대체제로서 이용하기 위 해서는 식육부산물이 가지고 있는 단백질기능 성 뿐만 아니라 제품 제조시 사용된 원료육 단 백질의 기능성과 가공적성이 동시에 고려되어 져야 할 것으로 사료된다.

\section{2. 프랑크푸르트 소시지 제조시 돼지 심장으 로부터 추출된 수리미유사물의 대체가 조 직감 및 관능적 특성에 미치는 영향}

프랑크푸르트 소시지 제조시 돼지 심장으로 부터 추출된 수리미유사물을 원료육에 대체하 여 제조된 제품의 조직감(TPA)은 Table 4에 나

Table 4. Effect of surimi-like material (SLM) from pig heart on texture profile analysis attributes of frankfurter sausage

\begin{tabular}{lcccc}
\hline Treatment & Hardness $(\mathrm{N})$ & Springiness $(\mathrm{mm})$ & Cohesiveness & Chewiness $(\mathrm{N})$ \\
\hline \hline Control & $69.4^{\mathrm{A}}$ & $8.52^{\mathrm{B}}$ & 0.65 & $398.4^{\mathrm{A}}$ \\
$5 \%$ SLM & $54.7^{\mathrm{BC}}$ & $8.98^{\mathrm{AB}}$ & 0.67 & $298.5^{\mathrm{BC}}$ \\
$10 \%$ SLM & $50.1^{\mathrm{C}}$ & $9.54^{\mathrm{A}}$ & 0.65 & $268.2^{\mathrm{C}}$ \\
S.E.M & 2.24 & 0.16 & 0.004 & 8.34 \\
\hline
\end{tabular}

${ }^{\mathrm{A}-\mathrm{C}}$ Means in the same column with different letters are different $(\mathrm{P}<0.05)$. 
타낸 바와 같다. TPA는 식품의 조직감을 평가 하기 위해 개발된 객관적인 분석방법으로(Pons 와 Foszman, 1996) TPA를 이용한 경도와 씹힘 성의 경우 수리미유사물 대체처리구가 대조구 에 비해 유의적으로 $(\mathrm{P}<0.05)$ 낮게 나타났으며, 처리구간에는 통계적인 차이가 나타나지 않았 다. 탄력성은 수리미유사물 $10 \%$ 대체처리구가 대조구에 비해 유의적으로 $(\mathrm{P}<0.05)$ 낮게 나타났 지만, 수리미유사물을 5\% 대체하였을 때에는 대조구와 유의적인 차이가 나타나지 않았다. 또한 응집성에 있어서는 대조구와 수리미유사 물 대체처리구간에 유의적인 차이가 없는 것으 로 나타났다.

수리미유사물의 원료육 대체가 프랑크푸르트 소시지의 조직감에 미치는 영향에 대한 본 연 구의 결과는 Desmond와 Kenny(1998)의 연구 결 과와 유사한 경향인데, 그들도 프랑크푸르트 소시지 제조시 수리미유사물을 대체하면 경도 와 씹힘성이 유의적으로 낮아지고 대체 첨가수 준이 증가할수록 경도와 씹힘성이 감소한다고 보고하였다. 또한, Totosaus(2004)도 소와 돼지 의 심장근육으로부터 추출된 수리미유사물을 제품에 첨가할 경우, 프랑크푸르트 소시지의 경도는 대조구에 비해 유의적으로 낮았다고 보 고하였고, Kenny 등(1992)도 5\% 수리미유사물 을 포함하는 재구성 쇠고기 로스트가 $5 \%$ 의 물 로 수세된 쇠고기에 비해 더 낮은 신장강도를 나타내었다고 보고하였다. 이 같은 결과는 이 미 예상된 것으로, 수리미유사물의 경우 수차 례의 세절과 수세과정을 통해 결체조직들이 제 거되고 근육의 미세조직들이 파괴됨으로써, 원 료육에 비해 단단한 조직감을 잃은 것과 수리
미유사물 자체가 가진 수분 함량에 의해 기인 된 것으로 사료된다. 본 연구의 결과에서 수리 미유사물을 원료육의 $10 \%$ 대체첨가할 경우, 프 랑크푸르트 소시지의 탄력성이 대조구에 비해 감소된 것은 부정적이지만, $5 \%$ 대체 첨가할 경 우에는 대조구와 탄력성이 차이를 나타내지 않 은 것은 주목할만한 결과로 생각된다. 또한 프 랑크푸르트 소시지의 응집성은 수리미유사물을 $10 \%$ 까지 대체 첨가하여도 대조구와 차이를 보 이지 않는 것은 매우 긍정적인 효과라고 사료 된다. 따라서 돼지 심장에서 획득한 수리미유 사물을 원료육에 대체 첨가한 프랑크푸르트 소 시지의 이러한 조직감적 특성은 관능적 특성에 도 부정적인 영향을 미치지 않을 것으로 추정 되며, 오히려 관능적으로 부드럽고 연하게 평 가될 것으로 예상된다.

수리미유사물 처리에 의한 프랑크푸르트 소 시지의 관능적 특성은 Table 5에 나타낸 바와 같다. 프랑크푸르트 소시지의 색에 있어서는, 관능적으로 대조구와 수리미유사물 대체처리구 간에 유의적인 차이가 없는 것으로 평가되었다 $(\mathrm{P}>0.05)$. 하지만 연도의 경우, 대조구에 비해 수리미유사물 대체처리구가 유의적으로 $(\mathrm{P}<0.05)$ 더 연하고 부드러운 것으로 나타났으나, 수리 미유사물 대체처리구간에는 유의적인 차이가 없는 것으로 나타났다. 이러한 관능적인 연도 는 예상된 바처럼 Table 4의 기계적으로 측정 된 경도 및 씹힘성의 결과와 일치하였는데, 이 러한 결과는 수리미유사물 대체처리구의 경우 결체조직이 제거된 것, 근육의 미세구조가 파 괴된 것 그리고 수리미유사물 자체가 보유한 수분 함량에 기인한 것으로 사료된다. 그러나

Table 5. Effect of surimi-like material (SLM) material from pig heart on sensory attributes of frankfurter sausage

\begin{tabular}{lccccc}
\hline \multirow{2}{*}{ Treatment } & \multicolumn{5}{c}{ Sensory analysis } \\
\cline { 2 - 6 } & Color & Tenderness & Juiciness & Flavor & Acceptability \\
\hline \hline Control & 5.13 & $4.5^{\mathrm{B}}$ & 4.8 & 4.2 & $4.4^{\mathrm{B}}$ \\
$5 \%$ SLM & 5.15 & $4.9^{\mathrm{AB}}$ & 4.7 & 4.5 & $4.7^{\mathrm{AB}}$ \\
$10 \%$ SLM & 5.17 & $5.3^{\mathrm{A}}$ & 4.9 & 4.4 & $5.0^{\mathrm{A}}$ \\
S.E.M & 0.11 & 0.24 & 0.12 & 0.13 & 0.16 \\
\hline
\end{tabular}

${ }^{A-B}$ Means in the same column with different letters are different $(\mathrm{P}<0.05)$. 
색, 다즙성과 풍미에 있어서는 대조구와 수리 미유사물 처리구간에 유의적인 차이가 없는 것 으로 평가되어 수리미유사물 처리가 소시지의 맛에 부정적인 영향을 미치지 않은 것으로 사 료된다. 오히려 종합적인 기호성에 있어서는 수리미유사물 대체처리구가 대조구에 비해 유 의적으로 $(\mathrm{P}<0.05)$ 더 좋게 평가되었으며, 수리 미유사물 대체처리구간에는 유의적인 차이가 없는 것으로 나타났다. 이렇게 관능평가 요원 들이 수리미유사물 대체처리구를 더 선호한 것 으로 평가한 것은 소시지의 씹힘성과 연도가 부드럽게 느껴진 점을 높이 평가한 것에 기인 한 것으로 사료된다.

본 연구의 관능검사 결과는 프랑크푸르트 소 시지 제조시 소 심장으로부터 추출한 수리미유 사물을 첨가한 처리구가 대조구에 비해 기호성 이 좋게 평가되었다고 보고한 Desmond와 Kenny (1988)의 보고와 같은 경향이다. McCormick 등 (1993)은 관능요원들이 5\% 어육 수리미와 양 수리미로부터 만들어진 재구성쇠고기 로스트간 의 차이를 구별하였으며, 대부분의 관능요원들 은 어육 수리미보다 양육 수리미를 더 좋아한 다고 보고하였다. 또한 어육 수리미의 경우 로 스트내 어육의 비린내가 관능요원에 의해 약간 감지되어 좋지 않은 결과를 가졌다고 하였다. 한편, Kang 등(2003)은 돼지 심장으로부터 추출 된 수리미유사물을 유화형소시지 제조시 대체 하였을 때 수리미유사물 대체처리구의 풍부한 향미가 전체적인 기호성을 향상시켰다고 보고 하였다. 따라서 프랑크푸르트 소시지 제조시 돼지 심장근육으로부터 획득한 수리미유사물을 원료육의 대체제로 $5 \%$ 와 $10 \%$ 로 이용할 경우 제품의 관능적 특성에 부정적인 영향이 크지 않은 것으로 사료된다.

\section{IV. 요 약}

돼지 심장근육으로부터 획득한 수리미유사물 을 프랑크푸르트 소시지 제조시 원료육에 $5 \%$ 와 $10 \%$ 로 대체 첨가할 경우 제품의 품질에 미 치는 영향을 알아보았다. 대조구와 비교해서 수리미유사물의 대체처리구가 가열 전 페티상
태에서의 수분과 지방 함량에 차이를 나타내지 않았지만 단백질 함량은 감소하였다. 대조구의 $\mathrm{pH}$ 는 수리미유사물 5\% 대체 첨가와 유의적인 차이를 보이지 않았지만, $10 \%$ 대체 첨가구에 비해 유의적으로 $(\mathrm{P}<0.05)$ 높게 나타났다. 반면 에, 대조구의 가열수율은 수리미유사물 $5 \%$ 대 체 첨가구와 유의적인 차이를 보이지 않았지만, $10 \%$ 대체 첨가구에 비해 유의적으로 $(\mathrm{P}<0.05)$ 낮게 나타났다. 조직감의 비교에서, 수리미유사 물의 대체 첨가가 우육과 돈육의 반막양근으로 부터 만들어진 소시지의 경도와 씹힘성을 감소 시키는 효과를 가진 것으로 나타났으며, 관능 평가에서도 연한 것으로 나타났다. 이러한 결 과는 제품의 외관, 색, 풍미 등과 함께 평가된 전체적인 기호성의 증가에도 영향을 미치는 것 으로 나타났다. 그러나 수리미유사물 $5 \%$ 와 $10 \%$ 대체 처리구간에는 통계적인 차이를 나타내지 않았다. 이상의 결과를 종합하면 경제적 측면 을 감안할 때, 프랑크푸르트 제조시 값비싼 원 료육의 비용절감 차원에서 값싼 돼지 심장근육 으로부터 수시미유사물을 추출하여 원료육의 $10 \%$ 까지 대체 첨가는 부분적으로 가능한 것으 로 사료된다. 반면에 돼지 심장근육으로부터 추 출한 수리미유사물을 프랑크푸르트 소시지 제 조시 이용할 경우 소 심장근육과 달리 낮은 가 열감량을 보였는데 이에 대한 보다 더 많은 연 구가 필요할 것으로 판단된다.

$$
\mathrm{V} \text {. 사 사 }
$$

본 연구는 산업자원부 지정 $\operatorname{RAIRC(ㄷㅗㅇㅁㅜㄹㅅㅐㅇㅁㅕㅇ~}$ 산업지역협력연구센터) 사업의 연구비 일부 지 원으로 수행되었기에 이에 감사드립니다.

\section{VI. 인 용 문 헌}

1. Antonomanlaki, R. E., Vareltzis, K. P., Georgakis, S. A. and Kaldrymidou, E. 1999. Thermal gelation properties of surimi-like material made from sheep meat. Meat Sci. 52:429-435.

2. Bourne, M. C. 1978. Texture profiling analysis. Food Tech. 37:62-66, 72. 
3. Botian, M. L., Fish, D. L., Webb, N. B. and Arey, J. J. 1985. Automated methods for determination of fat and moisture in meat and poultry products : collaborative study. J. Associ. Offi. Analy. Chem. 68:876-880.

4. Desmond, E. M. and Kenny, T. A. 1998. Preparation of surimi-like extract from beef hearts and its utilisation in frankfurters. Meat Sci. 50: 81-89.

5. Huxley, H. E. 1963. Electron microscope studies on the structure of natural and synthetic protein filaments from striated muscle. J. Mol. Biol. 7:281-308.

6. Kang, G. H., Oh, S. H., Yang, H. S., Kim, J. S., Joo, S. T. and Park, G. B. 2003. Effect of myofibrillar protein extracted from pig hearts on quality characteristics of emulsion type sausages. Kor. J. Food Sci. Ani. Resour. 23:122-127.

7. Kenney, P. B., Kastner, C. L. and Kropf, D. H. 1992. Muscle washing and raw material source affect quality and physicochemical properties of low-fat, restructured beef. J. Food Sci. 57:545-550.

8. McCormick, R. J., Bugren, S., Field, R. A., Rule, D. C. and Busboom, J. R. 1993. Surimi-like products from mutton, J. Food Sci. 58:497-500.

9. Nowsad, A. A. K. N., Kanoh, S. and Niwa, E. 2000. Thermal gelation characteristics of breast and thigh muscles of spent and broiler and their surimi. Meat Sci. 54:169-175.

10. Park, S., Brewer, M. S., Novakofski, J., Bechtel, P. J. and McKeith, F. K. 1996a. Process and characteristics for a surimi-like material made from beef or pork. J. Food Sci. 61:422-427.
11. Park, S., Brewer, M. S., McKeith, F. K., Bechtel, P. J. and Novakofski, J. 1996b. Salt, cryoprotectants and preheating temperature effects on surimi-like material from beef or pork. J. Food Sci. 61: 790-795.

12. Pons, M. and Foszman, S. M. 1996. Instrumental texture profile analysis with particular reference to gelled systems. J. Texture Stud. 267:597-623.

13. SAS. 2001. The SAS program for window. Cary, NC: The SAS Institute, Inc, USA.

14. Srinivasan, S., Xiong, Y. L. and Decker, E. A. 1996. Inhibition of protein and lipid oxidation in beef heart surimi-like material by antioxidants and combinations of $\mathrm{pH}, \mathrm{NaCl}$, and Buffer type in the washing media. J. Agric. Food Chem. 44:119-125.

15. Sweeny, R. A. and Rexford, P. R. 1987. Comparison of LECO FP-228 'Nitrogen Determinator' with AOAC Copper Catalyst Kjeldahl Method for Crude Protein. J. Associ. Offi. Analy. Chem. 70:10281030.

16. Totosaus, A. 2004. Functionality of glycosilated heart surimi and heart-precipitated whey proteins in meat batters. J. Muslce Foods, 15:256-268.

17. Winger, R. J. and Pope, C. G. 1981. Osmotic properties of post-rigor beef muscle. Meat Sci. 5:355-369.

18. Xiong, Y. L. and Blanchard, S. P. 1994. Myofibrillar protein gelation: viscoelastic changes related to heating procedures. J. Food Sci. 59:734-737.

(접수일자 : 2006. 1. 5. / 채택일자 : 2006. 5. 30.) 